\section{Isolating PCR-Quality DNA from Human Feces with a Soil DNA Kit}

\section{BioTechniques 28:640-646 (April 2000)}

Gastrointestinal (GI) microbial community dynamics influence host physiology and disease resistance. Assessing species presence and abundance over time is important for understanding GI community response to pathogens, diet and chronic disease (10). Recent advances have allowed researchers to examine the GI community using PCRbased methods $(11,12,13)$. These and newer methods such as terminal restriction fragment patterns (TRFP or TRFLP) $(3,8)$ share a need for relatively clean DNA that reflects the community structure of the original sample.

Fecal samples are a convenient means of studying the GI community, but they present problems in terms of DNA solution quality. Direct addition of fecal suspensions will inhibit PCR (1), and researchers have addressed this problem by separating cells and other fecal debris by dilution and centrifugation $(11,12,13)$. These techniques may eliminate cells attached to debris and bias any subsequent assay. To isolate community DNA without this bias, recent studies of different environments have used modified versions of the method of Boom et al. (2,3,7). Cell lysis (chemical and/or mechanical) is combined with protein denaturation and followed by purification of the DNA while bound to silica. Such methods are rapid and can produce DNA suitable for PCR directly from feces.

For our purposes, we desired a simple, commercially available kit for purifying microgram quantities of PCRquality DNA from human fecal samples as part of a 135-sample TRFP study. We adapted the UltraClean Soil DNA Isolation $\mathrm{Kit}^{\mathrm{TM}}$ (Mo Bio Laboratories, Solana Beach, CA, USA) for use with feces. The kit proceeds like Boom method derivatives with a notable exception: DNA purification and recovery is performed using a matrix immobilized on a small filter in a $2 \mathrm{~mL}$ centrifuge tube. These tubes are compatible with microcentrifuges for rapid, thorough washing and

Table 1. Normal Yield Protocol for Isolating DNA from Human Feces

Exceptions to the manufacturer's protocol are underlined.

1. Add $90-130 \mathrm{mg}$ feces to a pre-weighed lysis tube containing only beads. (Dry lysis tubes allow the adjustment of sample weight without dilution.)

2. Add $500 \mu \mathrm{L}$ "Bead Solution" and $60 \mu \mathrm{L}$ solution "S1", process for 10 at $4 \mathrm{~m} / \mathrm{s}$ on a FastPrep ${ }^{\mathrm{TM}}$ instrument (Bio 101, Vista, CA, USA) (lyses cells and denatures proteins).

3. Centrifuge for $5 \mathrm{~min}$ at $10000 \times g$ and transfer $450 \mu \mathrm{L}$ supernatant to a clean tube.

4. Add $250 \mu \mathrm{L}$ solution "S2", mix thoroughly and incubate at $4^{\circ} \mathrm{C}$ for $5 \mathrm{~min}$.

5. Centrifuge for $1 \mathrm{~min}$ at $10000 \times g$ and transfer $450 \mu \mathrm{L}$ supernatant to a clean tube (precipitates and pellets protein and other debris).

6. Add $900 \mu \mathrm{L}$ solution "S3", mix thoroughly and transfer $675 \mu \mathrm{L}$ into a "spin filter" tube (selectively binds DNA to the matrix immobilized on the filter).

7. Centrifuge the spin filter for $1 \mathrm{~min}$ at $10000 \times g$ and discard eluate.

8. Repeat steps 6 and 7 , then centrifuge for $30 \mathrm{~s}$ at $10000 \times g$ to dry the filter and discard any eluate. (The second wash step significantly clarifies the final DNA solution.)

9. Add $300 \mu \mathrm{L}$ solution "S4" to the filter, centrifuge for $30 \mathrm{~s}$ at $10000 \times \mathrm{g}$, discard eluate and repeat once (washes matrix-bound DNA to remove salts and other soluble compounds).

10. Centrifuge for $30 \mathrm{~s}$ at $10000 \times g$ to dry the filter (assures that ethanol/salt wash solutions will not contaminate final DNA solution).

11. Transfer filter unit to a clean tube and add $50 \mu \mathrm{L}$ solution "S5" directly onto the matrix.

12. Centrifuge for $30 \mathrm{~s}$ at $10000 \times g$ to elute DNA solution, remove filter unit and store as desired.

drying during DNA purification.

As part of our ongoing study, we determined maximum yield, average yield and efficiency of the DNA isolation kit. We also created TRFPs with spiked samples to determine the quantitative potential of the DNA isolation and subsequent PCR. Fecal samples were collected by Leatherhead (London, England, UK) and kept frozen at $80^{\circ} \mathrm{C}$. Two sample sets were used, maximum yield and normal yield. The maximum yield set consisted of four DNA isolation replicates from one sample and was used to determine efficiency and maximum possible DNA yield. The normal yield set consisted of all 135 fecal samples from which we determined PCR success and DNA yield for the normal protocol.

To isolate DNA, we adjusted the manufacturer's standard protocol (Table 1). For the maximum yield samples, the entire supernatant was recovered after lysis, and subsequent reagent vol- umes were adjusted accordingly. DNA was recovered from all of the maximum yield samples and 134 of the 135 normal yield samples. The protocol was completed on average in approximately $2 \mathrm{~h}$ with 24 samples and produced DNAs approximately $12 \mathrm{kbp}$ in length (Figure 1).

For maximum DNA yields, a second protocol was used. The entire supernatant was recovered after step 3 (Table 1), its volume estimated visually and the other volumes adjusted accordingly. As determined by PicoGreen ${ }^{\circledR}$ analysis (manufacturer's protocol; Molecular Probes, Eugene, OR, USA), maximum yield samples were between 64.2 and $85.5 \mu \mathrm{g} / \mathrm{g}$. We elected to use the normal protocol because it was faster and produced more than enough DNA for our study.

DNA concentrations for the normal yield samples were between 1.0 and $37.0 \mu \mathrm{g} / \mathrm{g}$ as determined by UV spectrophotometry. The differences in DNA 
content related to bacterial load were likely confounded by variation in sample water content. However, handling the samples "wet" allowed for rapid aliquoting and simple safety procedures.

To determine DNA recovery efficiency, direct epifluorescence microscopic counts were performed on sample 43A (the maximum yield sample source) following Kepner and Pratt (6). The extraction efficiency was greater than $100 \%$ (Table 2). However, the cellular DNA content estimate (5) that was used to calculate maximum possible yield ignores plasmid, viral and extracellular DNA as well as eukaryotic cells and pre-fission bacterial cells containing more than one genome. Also, debris and cellular aggregates, which can contribute to an underestimate of total cells (6), were observed on the fecal direct count slides.

To determine DNA solution quality, we performed PCRs using the normal yield samples. The PCR targeted an approximate $500 \mathrm{bp}$ region of the $16 \mathrm{~S}$ rRNA gene and was carried out in $50 \mu \mathrm{L}$ using 10,50 or $500 \mathrm{ng}$ of template DNA.

Table 2. DNA Yields, Direct Count Results and DNA Recovery Efficiency

\begin{tabular}{|c|c|c|c|}
\hline Value & $\begin{array}{c}\text { Mean } \\
\left(\mathrm{g} \text { feces }{ }^{-1}\right)\end{array}$ & $\begin{array}{l}\text { Standard } \\
\text { Deviation }\end{array}$ & Replicates \\
\hline \multicolumn{4}{|l|}{ Normal } \\
\hline Yield Protocol & $13.9 \mu \mathrm{g}$ DNA & 8.19 & $132^{b}$ \\
\hline \multicolumn{4}{|l|}{ Maximum } \\
\hline Yield Protocol & $75.5 \mu \mathrm{g}$ DNA & 9.64 & 4 \\
\hline \multicolumn{4}{|l|}{ Fecal Bacteria } \\
\hline Direct Count & $1.81 \times 10^{10}$ cells & $8.39 \times 10^{9}$ & 3 \\
\hline Efficiencya & $107 \%$ & $13.7 \%$ & \\
\hline \multicolumn{4}{|c|}{$\begin{array}{l}\text { aEfficiency is the observed yield expressed as a percentage of expected DNA } \\
\text { yield ( } 70.4 \mu \mathrm{g} / \mathrm{g} \text { feces). Expected yield was the product of the mean fecal cell } \\
\text { count and the mean prokaryotic cellular DNA content, } 3.89 \times 10^{-15} / \mathrm{g} \text { cell }(3.6 \\
\text { Mbp/cell [5] mutiplied by } 650 \mathrm{~g} \text { bp/mol). Standard deviation was estimated by } \\
\text { using the standard deviations for yield and direct count. }\end{array}$} \\
\hline
\end{tabular}

All other PCR conditions were as previously described (3) except for the fluorescently labeled forward primer $(\mathrm{Ba} 2 \mathrm{f}$ 5'-GCY TAA CAC ATG CAA GTC GA-3') and the $46.5^{\circ} \mathrm{C}$ annealing temperature. Reaction success was determined by agarose gel electrophoresis.

Previously, we determined that reliable community estimates could be made with 1 ng DNA per reaction in the PCR (data not shown), and our standard PCR for the TRFP method contains 10 ng DNA per reaction. All 134 normal yield samples were successfully amplified at this concentration without additional treatments. To test solution quality at higher DNA concentrations, eight normal yield samples were selected and used as PCR templates at 50 and $500 \mathrm{ng}$ per reaction. At $50 \mathrm{ng}$ per reaction, two samples amplified as expected. All eight samples failed to amplify at 500 ng per reaction (Figure 1). These data indicate that some inhibitors are still

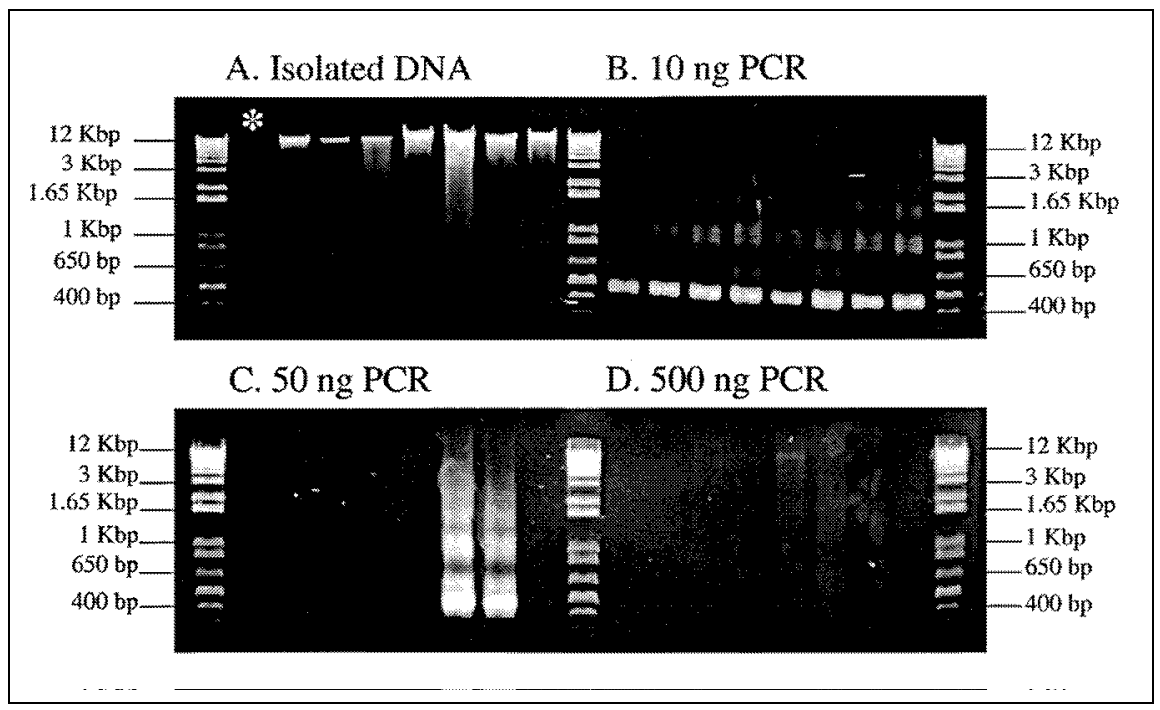

Figure 1. Electrophoresis of isolated DNA and subsequent PCR products ( 35 cycles). All panels are (left to right) samples 9A, 14A, 47A, 35B, 7C, 48C, 51C and 62C. (A) Isolated DNA. (B, C and D) PCR products using 10,50 and $500 \mathrm{ng}$, respectively, of template DNA. All samples $(5 \mu \mathrm{L})$ were analyzed with $1.5 \%$ agarose gels containing $0.5 \mu \mathrm{g} / \mathrm{mL}$ ethidium bromide. An approximate $12 \mathrm{kbp}$ band from sample $9 \mathrm{~A}$ was visible to the naked eye, but did not photograph well. 
carried over to the final solution, but that most PCR analyses can proceed. Studies requiring more template DNA for PCR could incorporate additional washes to further purify the sample DNA (step 6; Table 1). Alternatively, the manufacturer is now marketing an inhibitor removal solution with the kit, which may increase purity.

Another concern in any community analysis is proportional cell lysis and DNA recovery. Ideally, the abundance of a particular organism's DNA in the original sample. However, complex samples with free and attached cells at different levels of structural integrity present a challenge to even mechanical lysis methods. Furthermore, PCR is thought to skew product abundance relative to template abundance in multitemplate reactions (i.e., community analyses) $(4,9)$. Thus, many researchers analyze community data on a presence/absence basis. For our purposes, estimating abundance after PCR is of interest, and our data indicate that, with this protocol, abundance in the original sample may be calculated after DNA isolation and PCR. Briefly, we performed a spike experiment in which known quantities (by direct count) of the Gram positive bacterium Lactobacillus acidophilus were added to final solution will match that in the

aliquots of sample 43A. We performed TRFP analysis on the spiked samples and determined the relative abundance of $L$. acidophilus DNA fragments. When compared to abundance in the original sample, a strong linear relationship close to $1: 1\left(\mathrm{R}^{2}=0.999\right.$, slope $=0.91$; Figure 2 ) was observed. The addition of L. acidophilus did not obscure other community members from analysis at any level up to approximately $60 \%$, and its abundance could be assessed at about $1 \%$ of the total cells. While this is not conclusive proof of proportional lysis and DNA recovery, it indicates that quantitative analysis of difficult-to-lyse (i.e., Gram positive) cell types is possible using this method.

In summary, the UltraClean Soil DNA Kit produces PCR-quality DNA from human feces quickly and efficiently and appears to maintain original species abundance in the final DNA solution. Small modifications for fecal samples (dry lysis tubes and a second DNA wash step) were easy to incorporate. When optimized to recover the maximum DNA possible, the yield of this method was at or near $100 \%$. When optimized for speed and convenience, the method recovered enough DNA for 100-3700 PCR analyses from each sample. PCR was $100 \%$ successful using $10 \mathrm{ng}$ DNA, and the resulting prod-

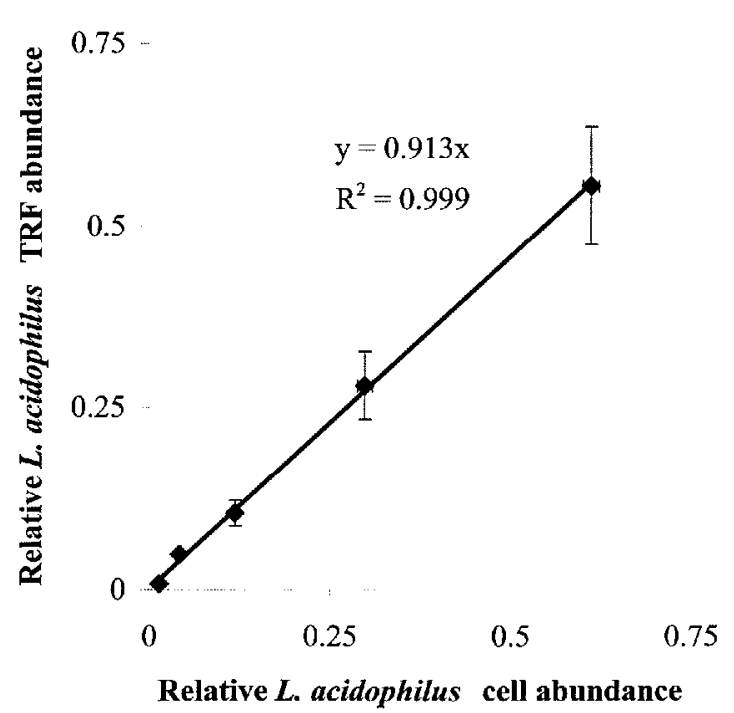

Figure 2. Post-PCR abundance correlates with cell abundance. Observed $L$. acidophilus TRF abundance correlated with $L$. acidophilus cell abundance in spiked fecal samples before DNA isolation. Each data point is the mean of four replicates. X-axis error bars indicate direct count variation; Y-axis error bars indicate TRF area variation. Error bars are \pm 1 standard deviation. ucts reflected the initial abundance of cells in each sample. This DNA isolation method, when paired with the PCR, can serve as a foundation for cloning, temperature/denaturing gradient gel electrophoresis (T/DGGE), TRFP or other studies of the human fecal microbial community.

\section{REFERENCES}

1.Al-Soud, W.A. and P. Rådström. 1998. Capacity of nine thermostable DNA polymerases to mediate DNA amplification in the presence of PCR-inhibiting samples. Appl. Env. Microbiol. 64:3740-3753.

2.Boom, R., C.J.A. Sol, M.M.M. Salimans, C.L. Jansen, P.M.E. Wertheim-van Dillen and J. van der Noordaa. 1990. Rapid and simple method for purification of nucleic acids. J. Clin. Microbiol. 28:495-503.

3.Clement, B.G., L.E. Kehl, K.L. DeBord and C.L. Kitts. 1998. Terminal restriction fragment patterns (TRFPs), a rapid, PCR-based method for the comparison of complex bacterial communities. J. Microbiol. Meth. 31:135-142.

4.Farrelly, V., F.A. Rainey and E. Stackebrandt. 1995. Effect of genome size and rrn gene copy number on PCR amplification of 16S rRNA genes from a mixture of bacterial species. Appl. Env. Microbiol. 61:2798-2801.

5.Fogel, G.B., C.R. Collins, J. Li and C.F. Brunk. 1999. Prokaryotic genome size and SSU rDNA copy number estimation of microbial relative abundance from a mixed population. Microb. Ecol. 38:93-113.

6.Kepner, R.L., Jr. and J.R. Pratt. 1994. Use of fluorochromes for direct enumeration of total bacteria in environmental samples: past and present. Microbiol. Rev. 58:603-615.

7.Kok, R.G., A. De Waal, F. Schut, G.W. Welling, G. Weenk and K.J. Hellingwerf. 1996. Specific detection and analysis of a probiotic Bifidobacterium strain in infant feces. Appl. Env. Microbiol. 62:3668-3672.

8.Liu, W.T., T.L. Marsh, H. Cheng and L.J. Forney. 1997. Characterization of microbial diversity by determining terminal restriction fragment length polymorphisms of genes encoding 16S rRNA. Appl. Envir. Microbiol. 63:45164522

9.Polz, M.F. and C.M. Cavanaugh. 1998. Bias in template-to-product ratios in multitemplate PCR. 1998. Appl. Env. Microbiol. 64:37243730.

10.Tannock, G.W. 1999. A fresh look at the intestinal microflora, p. 5-14. In G.W. Tannock (Ed.), Probiotics: A Critical Review. Horizon Scientific Press, Wymondham, England, UK.

11.Wang, R-F., W.W. Cao and C.E. Cerniglia. 1996. PCR detection and quantitation of predominant anaerobic bacteria in human and animal fecal samples. Appl. Env. Microbiol. 62:1242-1247.

12.Wilson, K.H. and R.B. Blitchington. 1996. Human colonic biota studied by ribosomal DNA sequence analysis. Appl. Env. Microbiol. 62:2273-2278.

13.Zoetendal, E.G., A.D.L. Akkermans and 
W.M. De Vos. 1998. Temperature gradient gel electrophoresis analysis of 16S rRNA from human fecal samples reveal stable and host-specific communities of active bacteria. Appl. Env. Microbiol. 64:3854-3859.

The authors wish to thank D. Elizondo and $M$. Shove for eliminating the fecal sample backlog, M.E. Sanders for funding efforts and guidance and R.J. Cano for providing equipment, space and intangibles. This study was funded by the National Dairy Council. Address correspondence to Dr. Christopher L. Kitts, Environmental Biotechnology Institute, Biological Sciences Dept., California Polytechnic State University, San Luis Obispo, CA 93407, USA. Internet: ckitts@calpoly.edu

Received 13 September 1999; accepted 30 November 1999.

Brian G. Clement and
Christopher L. Kitts
California Polytechnic
State University
San Luis Obispo, CA, USA

\section{Ethylene as a Gaseous Reporter Molecule for Monitoring Gene Expres- sion in Cultured Cells}

\section{BioTechniques 28:646-648 (April 2000)}

Reporters or signaling molecules are indispensable tools in current studies of gene activities, protein distribution, gene transfer and biosensing (2). A reporter molecule that is suitable for en masse measurement of gene activities in transgenic animals in a noninvasive manner is yet to be identified. We therefore intended to develop the plant hormone ethylene as a novel, noninvasive reporter molecule to profile spatial and temporal gene expression in animal cells. Here, we report the establishment of the plant ethylene biosynthetic pathway in an insect cell line IPLB-Sf21 of the fall armyworm Spodoptera frugiperda (3) as a step toward that goal.

Production of 1-aminocyclopropane-1-carboxylic acid (ACC)-dependent ethylene in higher plants is through the precursor S-adenosyl-Lmethionine (SAM). SAM is first converted to ACC by ACC synthase and then to ethylene by ACC oxidase (8). An artificial dual functional enzyme, $\mathrm{ACSO}$, has been created by in-frame fusion of ACC synthase and ACC oxidase (5). This fusion enzyme juxtaposes the active sites of ACC synthase with ACC oxidase in close proximity and catalyzes the two sequential steps of the ACC-dependent ethylene biosynthesis in an in vitro assay system (5), and it has been shown to produce ACC-dependent ethylene in the yeast Saccharomyces cerevisiae (7).

The insect cell line IPLB-Sf21 was purchased from Clontech Laboratories (Palo Alto, CA, USA). Production of the recombinant ACC oxidase fusion enzyme in the insect cells was carried out as reported (4). A $2.35 \mathrm{~kb}$ recombinant gene encoding the dual functional fusion enzyme ACSO (5) was inserted into the viral expression vector pBacPAK8, and the resultant recombinant clone was transfected into the insect cell line IPLB-Sf21. Ethylene and ACC productions by the transfected insect cells were determined according to the following method. After removing the spent medium, $5 \mathrm{~mL} 27^{\circ} \mathrm{C}$ TNM-FH medium (Grace's medium with $3.3 \mathrm{~g} / \mathrm{L}$ of lactabumin hydrolysate and $3.3 \mathrm{~g} / \mathrm{L}$ of yeastolate) were added to the culture flask, and the insect cells were detached from the flask wall by pipetting the medium up and down five or six times. Cells, at the density of $3 \times 10^{6}$ cells per $25 \mathrm{~mL}$ flask determined by using a hemocytometer, were incubated at $27^{\circ} \mathrm{C}$ for $3 \mathrm{~h}$. The medium was then removed, and $1.5 \mathrm{~mL}$ TNM-FH medium and 0.3 $\mathrm{mL}$ recombinant viruses $(\mathrm{moi}=10)$ were added to the cells. After incubation at $27^{\circ} \mathrm{C}$ for $1.5 \mathrm{~h}$, an additional 3.5 $\mathrm{mL}$ TNM-FH medium were added, and the culture was incubated at $27^{\circ} \mathrm{C}$. Two days later, iron (II) sulfate-7-hydrate and sodium ascorbate were added to the transfected cells to a final concentration of $100 \mu \mathrm{M}$ and $30 \mathrm{mM}$, respectively. The flask containing the transfected cell culture was sealed with a rubber septum and incubated at $27^{\circ} \mathrm{C}$ for $20 \mathrm{~h}$ before ethylene and ACC were quantitated. A gas sample of $2 \mathrm{~mL}$ in the headspace of the flask was removed for gas chromatography (1). Five hundred microliters of the cell culture were centrifuged at $2000 \times \mathrm{g}$ for $2 \mathrm{~min}$, and 450 $\mu \mathrm{L}$ supernatant were assayed for ACC content as previously described (6).

Table 1 shows that greater amounts of ACC and ethylene were produced by the insect cells transfected with the ACC oxidase recombinant virus. Around sixfold more ACC was produced by the ACSO cells. It was noted that the ACC concentration is a bit higher in the absence of ACC oxidase cofactors iron (II) and ascorbic acid. This correlates with increasing ethylene production under the same conditions. Much lower levels of ACC were observed in the control cells. The detected levels of ACC are not likely the result of authentic ACC molecules because the detection method we used, the Lizada and Yang assay, is known to generate background levels of artifacts (6). Ethylene production by insect cells in the presence of the ACC oxidase cofactors iron (II) and ascorbic acid was nearly sevenfold higher than ethylene production without these cofactors, which indicates that a functional ACC oxidase is present in the ACSO cells and that ethylene is able to diffuse 